\title{
AN ATTEMPT ON NEW SYSTEMATIZATION OF WORK MOTIVATION THEORIES
}

\begin{abstract}
The paper deals with a semiotic analysis of work motivation theories developed in the second half of the twentieth century. These theories stem from different theoretical backgrounds, varying in ideas as well as in their impact to work motivation reality. For a student approaching this field it might seem to provide an overwhelming situation in an area of study filled with contradictory theories. The method used in this study is similar to one historians use when analysing development in a human society - semiotic analysis. Based on the historical analysis, an analysis of ideas and clusters of meanings follows. Authors assume that personal experience might determine individual motivation factors. It is quite clear, that on the biological level the processes of motivation should be the same in all humans. However, stimuli or conditions under which the processes of motivation are commenced might be caused by the personal experience of the individuals concerned. Authors believe that the above mentioned analysis of clusters of meaning could help us to better systemize the wide range of work motivation theories and make it more evident for all students of the field.
\end{abstract}

\section{Luděk Kolman, Hana Chýlová, Richard Selby}

Czech University of Life Sciences Prague

kolman@pef.czu.cz

ARTICLE INFO

Article type

Short Communication

doi: 10.7160/eriesj.2012.050204

Article history

Received: April 27, 2012

Received in revised form: June 13, 2012

Accepted: June 13, 2012

Available on-line: June 30, 2012

\section{Highlights}

- New concept of systematization of the wide range of work motivation theories

- Semiotic analysis used as a conceptual tool

- Personal experience potentially determining individual motivation factors taken into account

\section{Key Words}

Work motivation, theories, semiotic analysis, systematization

Kolman, L., Chýlová, H., Selby, R. (2012) "An Attempt on New Systematization of work Motivation Theories", Journal on Efficiency and Responsibility in Education and Science, Vol. 5, No. 2, pp. 92-98, ISSN 1803-1617, [on-line] www.eriesjournal.com/_papers/article_170.pdf 


\section{Introduction}

The development of work motivation theories in the second half of the twentieth century is a phenomenon which deserves study in its own right. It appears to be a succession of meanings and ideas, sometimes supporting and sometimes opposing one another. This might be a regular part of the development of a scientific field of study. The number of theories developed, tested, and generally dismissed afterwards was rather large. If there are too many theories concerning one thing, it might be assumed, there is a lack of understanding of the phenomena studied. Another possible explanation of the number of work motivation theories appearing at that time might stem from the need to study and explain diverse aspects of work motivation. If it would be so, however, one would expect some cooperation or complementarities between different theories. This does not seem to have happened. Every one of the succession of work motivation theories tried to explain the field as a whole and as such was tested, received some support, and in due time was substituted by the next. This problem has already been addressed by other authors (see Locke and Latham 2004). In this paper we propose a perspective which might help in achieving the aims they suggested.

In this paper we advocate the idea that the field of work motivation is really very complex and that the students of it approached the field from different perspectives. These perspectives were derived from, or connected to, ideas and ideals concerning many diverse things which work stands for in human lives. Because of it, the perspectives on human motivation mirrored in the work motivation theories are connected to clusters of ideas. These clusters could be called ideologies, like man as a machine, or protestant ethic. Consequently, the theories expounding such clusters of ideas used specific sets of meanings. The question is whether an analysis of meanings and ideas employed in the work motivation field could help us to further our understanding of the field. The current authors believe it could.

\section{Method}

The method employed in this study is akin to the one a historian uses when she/he tries to analyse development in a human society. Accordingly, the main part of the analysis will stem from following these developments in the field since the early $20^{\text {th }}$ century. Based on the historical analysis, an analysis of ideas and clusters of meaning will follow. Such clusters might be considered as sources of ideologies (e.g. of work and/or work behaviour), where by ideology is meant a worldview. The term ideology has many other connotations which might clash with the aims of this paper, so for this reason we prefer to speak here about semiotic analysis. (An alternative would have been to call the clusters of meanings metaphors, but an analysis of metaphors would be more complicated.)

Semiotics is commonly understood as a study of signification and communication. To justify the use of the term semiotics, and by calling the method employed in this paper a semiotic analysis, it is necessary to make a proviso. This proviso is that the term semiotics is used here in a rather broad sense, implying that this analysis will deal with the meanings assigned to human behaviours, feelings and thoughts and the ways they are used in interpretations of the same behaviours, feelings and thoughts. The interpretations should be understood as the work motivation theories. For the definition of semiotics presented here and semiotics in a broad sense, see e.g. Eco (1976, p. 27). 


\section{Theory}

A possible way in which historical and semiotic analyses might become intertwined might easily ensue from a brief review of work and motivation theories from the first half of the twentieth century. It all started in the 1911, when Taylor's monograph, The principles of scientific management, was published (Myers 2011). Taylor's efforts were probably the first attempt to study work behaviour and jobs. For Taylor, a job was something mechanical, which could be developed to a higher standard by an engineer in a similar way as machines can be improved by experts. This perspective on work was commonly held through the first part of the twentieth century. Even in 1948, Bartlett compared in his paper modifications of work procedures to modifications of a machine (Bartlett 1948). At that time, the results of the Hawthorn studies had become known, and this brought about a change of the paradigm. The new ideas on work and work behaviour received full expression as recently as 1960 in McGregor's The Human Side of Enterprise (1960).

McGregor's theory $Y$ was widely accepted as a formulation of a humanistic conception of work. For many professionals in the field it stood for a new and morally superior view to the one represented by its opposite, the theory $X$. This wide acceptance and acclaim of the theory $\mathrm{Y}$ is significant, especially as careful reading of McGregor's works shows his own views were different. With the theory $\mathrm{Y}$ humanism developed in a very important stream of thought concerning work motivation. Shortly afterwards Maslow's theory has arrived, followed by variations on the same theme such as Alderfer's theory (Alderfer 1972). These ideas were overly humanistic, and humanist thinking stays with us to these days as an important asset of psychological empowerment (Ahearne, Mathieu, Rapp 2005). If we understand the meaning of empowerment correctly, it says: give the worker freedom and she/he will be happy and will produce (Mathieu, Gilson, Ruddy 2006).

McClelland's theory (1961) dealt with needs like Maslow's, but in a different way. The achievement was for McClelland a selfstanding quality which was good for the society (if, perhaps, not always for the individual). The achievement is about striving to achieve something specific. In goal-setting theory there seems to be a similar idea - according to Locke (1981), the most important ingredient of motivation induced by a goal was a commitment to it. In this theory again, the effort, the striving is an important value by itself and on its own. In both the theories, striving (to achieve or to meet a goal) is understood as a general good. This understanding of what work means in the life of a human being is akin to protestant ethic as described by Max Weber (1976) half a century ago.

For several decades Vroom's expectancy theory was rather influential. Vroom (1964) understood motivation as a power to act, which resulted from the simultaneous influence of three components called expectancy, instrumentality and valence. Vroom's theory is not machine-like. The assumed operations of the three components resemble rather a physiological process. In the eighteenth century the French philosopher, de la Mettrie (Thomson 1996), published two essays entitled L'Homme Machine and L'Homme Plante. If we would accept L'Homme Machine as a predecessor of the man-as-a-machine concept, then we could take L'Homme Plante as a model for Vroom's concept or, perhaps, call Vroom's concept man-as-a-living-organism.

Another approach to motivation originated with Adams' equity theory (Adams, 1965), from which developed a number of theories dealing with perceived justice at the work-place together with the theories of organizational citizenship (Podsakoff et al. 2000). These theories understand the processes of work motivation as 
a result of the social perception and interaction of the worker and her/his co-workers. In this case the conceptual model could be called man-as-a-social-being or, in the case of organizational citizenship theories, work as a social institution.

Psychological empowerment theory was briefly mentioned above in connection with humanistic ideals. Empowerment theory is based on them, and the same holds for Herzberg's theory as well as for Hackman and Oldham's conception. In empowerment (Chen et al. 2007) the freeing of an employee is typically achieved by job enrichment procedures which were proposed originally by Herzberg. Hackman and Oldham's (1980) idea presupposes that a job will motivate the worker, if it takes on specific qualities. These qualities are those which sustain human worth, dignity and meaningfulness of the activities on the job. It might be argued, though, that in the theories discussed in this paragraph elements of protestant ethic could be identified as well. All of them find job and work as something good in itself, under the condition that the job or the work supports human interests or values.

\section{Results}

The discussion of the work motivation theories indicates five clusters of meanings (or ideologies). To analyse these clusters a little further, we could employ definitions of the core concepts of the clusters. That way, the clusters (or ideologies) could be described, as follows:

1. Man-as-a-machine: a whole composed of parts; uninfluenced by mind or emotions; automatic; governed by, or in accordance with the principles of mechanics; related to the quantitative relations of force and matter;

2. Man-as-an-organism: a whole composed of parts, internally organized and coordinated; having the characteristics of an organism;

3. Man-as-a-social-being: involving allies or confederates; relating to human society, the interaction of the individual and the group, or the welfare of human beings as members of society; tending to form cooperative and interdependent relationships with others;

4. Protestant ethic: the value is attached to hard work, thrift, and efficiency in one's worldly calling;

5. Humanistic: centred on human interests or values; the belief that humans, as individuals, are unique beings and should be recognized and treated as such; a concern with the fullest growth of the individual in the areas of love, fulfilment, self-worth, and autonomy.

The five clusters of meanings (or ideologies) associated with work and activities on a job could be construed in at least two ways. Obviously, we might understand the five clusters as standing for five distinct areas of interest concerning the study of human labour. In such a case it would make sense to ask whether the five clusters cover all the important things in the field of work motivation. Or, perhaps, if some clusters are represented in more or less detail as others. In both cases, asking the questions will help to develop the theory of work motivation and further its utility.

Another view is the ideological one. If we would call the clusters of meanings as ideologies, this would lead to questions of a different kind. First of all the term "ideology" is emotionally laden with both positive and negative aspects. On one side it might be understood as just a point of view, and on the other as an opinion which is pushed through to serve someone's interest. Again, in both cases, we could ask why somebody has chosen this and not some other opinion and whether or not it 
has served some purpose. Of course, asking these questions might make sense only if there is no unequivocal winner, a theory widely accepted as the only true one. It goes without saying that for many work and organizational psychologists, the theory of psychological empowerment would be a good candidate for this position.

Psychological empowerment developed in recent years is a rather sophisticated concept, supported by considerable research data. Even so, the same has held for practically all the work motivation theories mentioned above. These theories were widely accepted and supported by numbers of empirical studies in their own time. In the next part of the paper we will discuss both the reasons why the same fate might lay ahead for the empowerment theories in future developments of the work motivation theories (Wosnitza et al. 2009) and try to answer these questions.

\section{Discussion and conclusions}

Humanism is a nice idea and a very Western one. It seems to be a powerful and recurrent theme in work motivation theories. Part of the problem with humanist ideals stems from their Western origin. Because of it they are culturally determined and so they do not have to represent the preferred values of non-Western countries (Hofstede, Hofstede 2005). The Czech Republic is located in Middle Europe and it is one of the postcommunist bloc countries. In the last decade we have conducted two surveys on work motivation (Kolman 2001, Michálek et al. 2006) and some results suggest that respondents who are older, less educated and live on the country margins understand performance on the job in a different way than their younger, more educated and living in the central part of the country counterparts. These two kinds of respondents differ mainly in their experience on the job. The younger ones believe that to produce on a job will bring rewards to them. The others do not believe it is so. This finding lets us conclude that to fully grasp what the processes and the content of work motivation are, we have to take into account what job and working signify to those whose work motivation we try to research.

The use of the word "signify" in this place brings us back to semiotics. A job and working activities might mean very different things to people of diverse cultural origins, of diverse social standing and those who hold different beliefs on what work and/or being on a job stands for in their lives. If the scope of work motivation theory is enlarged accordingly, it would become clear that this field really is very complex. It might be extremely difficult or, perhaps, impossible to build one unified theory which would cover it in all its intricacy. At the same time, new themes are arriving incessantly (Latham and Ernst 2006, Masuda et al. 2012), new points of view which would differ from those we have introduced above. For somebody a job might primarily be a social role. For someone else it might be a way to develop as a human being and for another person just a toil which cannot be avoided. These different viewpoints may lead to different concepts on work motivation.

One of the recommendations Locke and Latham (2004) proposed was to "integrate extant theories by using existing meta-analyses to build a megatheory of work motivation". Semiotic analysis might help in this as a conceptual tool.

\section{Acknowledgements}

This paper was written with a support provided from the Czech Science Foundation GACR P407/10/1262 Work motivation, values and attitudes. 


\section{References}

Adams, J. S. (1965): Inequity in social exchange. In: Berkowitz, I. (Ed.) Advances in Experimental Social Psychology, 69, 334-45.

Alderfer, C. P. (1972) Existence, Relatedness and Growth: Human need in organizational settings. New York: Free Press.

Ahearne, M. M.; Mathieu, J.; Rapp, A. (2005) To empower or not to empower your sales force? An empirical examination of the influence of leadership empowerment behavior on customer satisfaction and performance. Journal of Applied Psychology, 90 (5), 945-955.

Bartlett, F. C. (1948) Men, machines, and productivity, Occupational Psychology 22, 190-196.

Chen, G.; Kirkman, B. L.; Kanfer, R.; Alen, D.; Rosen, B. (2007) A multilevel study of leadership, empowerment and performance in teams. Journal of Applied Psychology, 92 (2), 331-346.

Eco, U. (1976) Theory of Semiotics. Indiana University Press, Bloomington.

Hackman, J. R.; Oldham, G. R. (1980) Work redesign. Reading, MA: Addison-Wesley.

Hofstede, G., Hofstede, G. J. (2005) Cultures and Organizations. Software of the Mind. London: McGraw Hill.

Kolman, L. (2001) Motivation and attributive processes. Agrární perspektivy X., Praha: ČZU, September 2001.

Locke, E. A. et al. (1981): Goal setting and task performance: 1969-1980, Psychological Bulletin, 90, 125-52.

Locke, E. A.; Latham, G. P. (2004) What should we do about motivation theory? Six recommendations for the twenty-first century. Academy of Management Review, 29, 3, 388-403.
Latham, G. P.; Ernst, C. T. (2006) Keys to motivating tomorrows workforce. Human Resources Management Review, 16, 181-198.

Masuda, A. D.; Poelmans, S. A. Y.; Allen, T. D.; Lapierre, L. M.; Cooper, C. L.; Abarca, N.; Brough, P.; Ferreiro, P.; Fraile, G. (2012) Flexible work arrangements avalaibility and their relationship with work-to-family conflict, job satisfaction and turnover intensions: A comparison of three country clusters. Applied Psychology, 61, 1-29.

Mathieu, J. E.; Gilson, L. L.; Ruddy, T. M. (2006) Empowerment and team effectiveness: An empirical test of an integrated Model. Journal of Applied Psychology, 91 (1), 97-108.

McClelland, D. C. (1961) The Achieving Society. New York: Van Nostrand.

McGregor, D. (1960) The Human Side of Enterprise. New York: McGraw Hill.

Michálek, P; Chamoutová, H..; Kolman, L.; Chamoutová, K.; Rymešová, P. (2006) Motivace pracovní činnosti a kvalita života při práci na českém venkově - část II. (Work motivation and work life quality in the Czech countryside - part II.) Psychologie v ekonomické praxi, XLI, p. 185-191.

Myers, L. A., Jr. (2011) One Hundred Years Later: What Woul Frederick W. Taylor Say? International Journal of Business and Social Science, 2 (20), 8-11.

Podsakoff, P. M., MacKenzie, S. B., Paine, J. B., Bachrach, D. G. (2000) Organizational Citizenship Behaviors: A Critical Review of the Theoretical and Empirical Literature and Suggestions for Future Research. Journal of Management, 26, 3, 513-563.

Thomson, A. (1996) La Mettrie: Machine Man and Other Writings. Cambridge: Cambridge University Press. 
Journal on Efficiency and Responsibility in Education and Science

Vroom, V. H. (1964): Work and Motivation. New York: John Wiley \& Sons.

Weber, M. (1976) The Protestant Ethic and the Spirit of Capitalism. London: George Allen \& Unwin.

Wosnitza, M. et al. (2009) Contemporary motivation research: From global to local perspectives. Ashland: Hogrefe and Huber Publishers. 